\title{
Evaluation of expression profiles of microRNAs and two target genes, FOXO3a and RUNX2, effectively supports diagnostics and therapy predictions in breast cancer
}

\author{
D. JURKOVICOVA ${ }^{1,2, *}$, M. MAGYERKOVA ${ }^{1}$, Z. SESTAKOVA ${ }^{2}$, L. COPAKOVA ${ }^{3}$, V. BELLA ${ }^{4}$, M. KONECNY ${ }^{4}$, M. KRIVJANSKA ${ }^{1}$, L. KULCSAR ${ }^{1}$, \\ M. CHOVANEC ${ }^{1,2}$
}

${ }^{1}$ KRD Molecular Technologies Ltd., Saratovska 26, 84201 Bratislava, Slovakia; ${ }^{2}$ Biomedical Research Center, Cancer Research Institute, Slovak Academy of Sciences, Dubravska cesta 9, 84505 Bratislava, Slovakia; ${ }^{3}$ National Cancer Institute, Department of Clinical Genetics, Klenova 1, 83310 Bratislava, Slovakia; ${ }^{4}$ St. Elisabeth Cancer Institute, Department of Clinical Genetics and Department of Mammology, Heydukova 10, 81250 Bratislava, Slovakia

*Correspondence: dana.j@krdlab.sk

Received July 20, 2016 / Accepted August 31, 2016

\begin{abstract}
Breast cancer (BC) including its progression into bone metastasis is a complex process involving changes in gene expression and function of both, microRNAs (miRNAs) and their target genes. Deregulation of miRNAs has been described as a crucial factor responsible for the initiation and progression of $\mathrm{BC}$, and specific miRNA expression profiles have been found to be associated with particular disease states, histological tumor types, and BRCA1/2 or HER status. BRCA1 tumor suppressor is involved in DNA damage response and repair and epigenetically controls miR-155 expression and its pre-cancerous potential. MiR-155 targets 3'UTR region of multiple components of the pro-oncogenic signaling cascades, including FOXO3a tumor suppressor and RUNX2 transcription factor regulating metastatic potential in BC. We employed qRT-PCR to determine expression level and examine possible regulatory role of selected miRNAs (miR-17, miR-18a, miR-19a, miR-20a, miR-21, miR-27a and miR-155) and their impact on expression modulation of FOXO3a and RUNX2 in peripheral blood mononuclear cells (PBMCs) in healthy individuals, in women carrying BRCA1 mutations with no disease manifestation, in women carrying $B R C A 1$ mutations after tumor resection and therapy and in women with $\mathrm{BC}$ of unknown $B R C A 1$ status in acute stage before tumor resection. Our results showed significant increase of miR-17, miR-19a, miR-21, miR-27, miR-155 and RUNX2 expression in PBMCs in BRCA1 patients and patients in acute stage, while FOXO3a expression was significantly decreased in these patients. MiR-18a and miR-20a expression was not affected. We propose that expressional changes reported in this study could provide significant additive information for early BC diagnosis, disease development prediction and therapy outcome monitoring.
\end{abstract}

Key words: miRNA, target genes, breast cancer, peripheral blood mononuclear cells, BRCA1

Breast cancer $(\mathrm{BC})$ is the most common cancer in women worldwide and the second most common cancer overall. It is a leading cause of cancer death in less developed countries and the second leading cause of cancer death in American and EU women, exceeded only by lung cancer. BC comprises approx. $10.4 \%$ of all cancer incidences among women [1], and $21 \%$ of all new cancer diagnoses [2]. In 2013, BC led to death of about 88,886 women in Europe and 39,620 women in the US [3].

This malignant neoplasm originates from breast tissues, and its advanced form tends to metastasize into bone. Striking incidence and mortality numbers could be decreaed if efficient screening, early diagnosis and subsequent patientmonitored therapy leading to successful treatment were employed. Significant effort has been put into searching for efficient and informative biomarkers. However, due to lack of sensitivity and specificity of known biomarkers, especially in early disease stages, there is no available efficient biomarker up to now $[4,5]$.

MicroRNAs (miRNAs, 22 nucleotides long) belong to a highly promissing class of endogenous interfering RNAs that play a crucial role in post-transcriptional gene silencing. By targeting messenger RNAs (mRNAs) miRNAs partici- 
pate in many biological processes encompassing apoptosis, cell-cycle control, cell proliferation, DNA repair, immunity, metabolism, stress, aging etc. [6]. MiRNAs are remarkably stable in plasma due to their association with RNA binding proteins (Ago2 protein) and exosomal vesicular transportation proteins $[7,8]$. Therefore, miRNAs are detectable by a noninvasive diagnostic approach of liquid biopsy. Representing tumor-derived molecules released early into circulation and reflecting tumor initiation and development, miRNAs are recognized as promising early diagnostic, prognostic and predictive biomarkers of $\mathrm{BC}$.

As reported in several studies, miRNA-155 (miR-155), miR-17 92 cluster (miR-17, miR-18a, miR-19a, miR-20a, miR-19b-1 and miR-92a-1), miR-21 and miR-27a are known potent oncogenic miRNAs playing an important role in tumorigenesis and progression of many cancers including BC [9-14]. Their up-regulation is associated with progression of cancer pathogenesis.

Up-regulation of miR-155, the key oncogenic miRNA, associates with promotion of tumorigenesis in BC [15]. Overexpression of miR- 155 can be triggered by mutation of BRCA 1 (breast cancer 1, early onset), well-known tumor suppressor involved in DNA damage response and repair. BRCA1 plays a role in regulation of transcription through interactions with histone deacetylase complexes (HDACs) $[15,16]$. Mutations in the BRCA1 gene are considered a genetic predisposing factor in approx. $21 \%$ of women. In human cell lines deficient in $B R C A 1$, miR-155 levels were up-regulated 50-fold compared to cells with functional BRCA1 [16]. Highly up-regulated miR-155 in pathogenesis of $B C$ results in down-regulation of tumor suppressor targets and consequent up-regulation of tumor genes expression reflecting regulatory pathways' activation in $\mathrm{BC}$ development and progression.

FOXO3a protein belongs to the forkhead/winged-helix family of FOXO transcriptional regulators controlling DNA binding interactions during transcription. These transcription factors regulate many cellular processes and functions, including survival, proliferation, differentiation, cell-cycle progression and arrest, DNA damage response and repair and cell death $[17,18]$. Down-regulation of FOXO3a activity is often seen in cancers and ERK- or inhibitor kappa B kinase (IKK $\beta$ )-mediated inhibition of FOXO3a has been shown to promote tumorigenesis $[19,20]$. MiR-155 directly targets $3^{\prime}$ UTR of FOXO3a and represses its protein expression. On the other hand, FOXO3a binds to the promoter region of miR-21 and suppresses its promoter activity [21]. FOXO3a was also verified as a new target of miR-27a in glioblastoma cells and administration of antagomiR-27a inhibited the proliferation and invasion ability of glioblastoma cells [22].

Runt-related transcription factor 2, RUNX2, is another direct target controlled by deregulated miR-155. It has been shown to importantly control osteogenesis and development of osteosarcoma orchestrating the bone developmental program in mammals [23]. Originally, this transcription factor was thought to contribute to skeletal formation [24], but recent research data indicates that RUNX2 may be a potential target for inhibiting metastatic growth of BC cells [25]. RUNX2 is reported to be a "master" transcription factor of metastatic growth of $\mathrm{BC}$ cells and its high expression has been shown to be associated with poor clinical outcomes in this diagnosis [26].

In present study, we have examined possible regulatory roles of selected miRNAs (miR-17, miR-18a, miR-19a, miR-20a, miR-21, miR-27a and miR-155) in BC tumorigenesis through their impact on expressional modulation of the two key regulators of this process, FOXO3a and RUNX2. In addition, a link between BRCA1 and these miRNAs and their two targets has been studied. We propose that expressional changes reported in this study could provide significant additive information for early BC diagnosis, disease development prediction and therapy outcome monitoring.

\section{Patients and methods}

Patient samples. Blood samples were obtained from Department of Clinical Genetics, National Cancer Institute, Bratislava, Slovakia and Department of Clinical Genetics, St. Elisabeth Cancer Institute Ltd., Bratislava, Slovakia. Four groups of samples were included: (i) 13 healthy individuals (age 27-44) (from now on referred to as Healthy control group 1), (ii) 14 women carrying BRCA1 mutations with no disease manifestation (age 25-46) (from now on referred to as BRCA1 carriers with no disease manifestation - group 2), (iii) 10 women carrying $B R C A 1$ mutations after tumor resection and 4-6 years after chemotherapy (age 27-61) (from now on referred to as $B R C A 1$ carriers with $\mathrm{BC}$ - group 3 ), and (iv) 30 women with $\mathrm{BC}$ of unknown $B R C A 1$ status in acute stage of disease before tumor resection (age 36 -78) (from now on referred to as Acute BC patients - group 4). Five of $B R C A 1$ positive patients reported familial history of breast, ovarian or prostate cancer, but none of the affected relatives was available for testing. The retrospective study in patients revealed two prevailing BRCA1 mutations - p.Cys61Gly and c.5266dupC. These mutations were detected also in healthy high-risk individuals, considering these familial cases. Both, p.Cys61Gly and c.5266dupC, belong to founder mutations that are frequent in Slavic nations and many European countries $[27,28]$. Other five $B R C A 1$ positive patients provided no information on familial history of breast cancer and were considered as sporadic cases. In a group 4 , invasive ductal and invasive lobular carcinomas were preferentially diagnosed by conventional diagnostic methods.

The study was approved by the Scientific and Ethical Committees of the National Cancer Institute, Bratislava, Slovakia and St. Elisabeth Cancer Institute Ltd., Bratislava, Slovakia. All subjects donated their samples with informed consent approved by the Ethic Committee of the Institute of Hematology and Blood Transfusion and each patient/donor gave written informed consent in accordance with the Declaration of Helsinki. PBMCs were prepared by sedimentation using 
Ficoll-Paque ${ }^{\mathrm{TM}}$ PLUS (GE Healthcare, Freiburg, Germany) density gradient. Cells were resuspended in freezing solution (DMEM supplemented with $10 \%$ DMSO and $20 \%$ fetal calf serum) and stored at $-80^{\circ} \mathrm{C}$ before RNA extraction.

RNA extraction. To extract total RNA containing all small RNA molecules including miRNAs, TRI Reagent solution (Life technologies), Ribo Pure-Blood kit (Ambion Inc., no. AM1928, Austin, TX, USA) and RNA/DNA/Protein Purification Kit (Norgen Biotek ${ }^{\circledast}$, Thorold, ON, Canada) were used. Total RNA was quantified using the NanoDrop ND-1000 Spectrophotometer (Thermo Scientific, USA) and the Qubit fluorometer (Qubit ${ }^{\star}$ RNA HS Assay Kit, LifeTechnologies, USA).

miRNA qRT-PCR quantification. Differentially expressed oncogenic miRNAs, miR-17, miR-18a, miR-19a, miR-20a, miR-21, miR27a and miR-155 were evaluated in PBMCs by qRT-PCR. Expression of mature miRNAs was determined using First-Strand cDNA Synthesis System (Central European Biosystems, Czech Republic) supplemented with poly(A)polymerase (Takara, Japan) and ATP (Sigma, Germany). Briefly, for cDNA synthesis $100 \mathrm{ng}$ of RNA in a final volume of $10 \mu$ including $1 \mu \mathrm{l}$ of $10 \mathrm{x}$ poly(A) polymerase buffer, $0.1 \mathrm{mM}$ of ATP, $1 \mu \mathrm{M}$ of RT-primer, $0.1 \mathrm{mM}$ of each deoxynucleotide (dATP, dCTP, dGTP and dTTP), 100 units of MuLV reverse transcriptase and 1 unit of poly(A)polymerase was incubated at $42^{\circ} \mathrm{C}$ for 1 hour followed by enzyme inactivation at $95^{\circ} \mathrm{C}$ for 5 minutes. The sequence of the oligo-d(T)/adapter primer was $5^{\prime}$-CAGGTCCAGTTTTTTTTTTTTTTTVN, where V is A, C and $\mathrm{G}$ and $\mathrm{N}$ is $\mathrm{A}, \mathrm{C}, \mathrm{G}$ and $\mathrm{T}$ (IDT, Leuven, Belgium).

Real-time PCR detection and quantification of mature forms of hsa-miR-17-5p, hsa-miR-18a-5p, hsa-miR-19a-3p, hsa-miR-20a-5p, hsa-miR-21-5p, hsa-miR-27a-3p, hsamiR-155-5p and small RNA reference endogenous control Snord44 were performed using SYBR Premix Ex Taq II (Tli RNaseH Plus), ROX plus (Takara, Japan), adapterspecific reverse primer and miRNA-specific (and Snord44 specific 5'CCTGGATGATGATAAGCAAAT'3) forward primers (http://registre.indprop.gov.sk/registre/detail/popup. do?register=uv\&puv_id=668162, http://registre.indprop.gov. sk/registre/detail/popup.do? register=uv\&puv_id=668163, http://registre.indprop.gov.sk/registre/detail/popup. do? register=uv\&puv_id=668166, http://registre.indprop.gov. sk/registre/detail/popup.do? register=uv\&puv_id=668174, http://registre.indprop.gov.sk/registre/detail/popup. do? register=uv\&puv_id=668175,

http://registre.indprop.gov.sk/registre/detail/popup. do? register=uv\&puv_id=318681 and for miR-19a-3p: 5 ' CAGTGTGCAAATCTATGCAA`3). qPCR was performed using BIOER, LineGene 9660 Real-Time PCR System (Hangzhou Bioer Technology Co., Ltd, China) at following settings: $95^{\circ} \mathrm{C}$ for $5 \mathrm{~min}$, followed by 40 cycles of $95^{\circ} \mathrm{C}$ for $20 \mathrm{sec}$ and $60^{\circ} \mathrm{C}$ for $50 \mathrm{sec}$, followed by melt cycle. Mature miRNA amplification was done in triplicate. Ct values were averaged and normalized against reference endogenous control Snord44. Relative expression was determined by the $2^{-(\Delta \Delta C t)}$ comparative threshold method.

Target gene qRT-PCR quantification. Differentially expressed target genes FOXO3a and RUNX2 were evaluated by qRT-PCR using First-Strand cDNA Synthesis System (Central European Biosystems, Czech Republic). Briefly, for cDNA synthesis in a final volume of $10 \mu \mathrm{l}, 500 \mathrm{ng}$ of total RNA, $2 \mu \mathrm{l}$ of $10 \mathrm{x}$ MuLV buffer, $1 \mu \mathrm{M}$ of $\mathrm{p}(\mathrm{dN}) 6$ primer, $0.1 \mathrm{mM}$ of each deoxynucleotide (dATP, dCTP, dGTP and dTTP) and 100 units of MuLV reverse transcriptase were incubated at $42^{\circ} \mathrm{C}$ for 1 hour followed by enzyme inactivation at $95^{\circ} \mathrm{C}$ for 5 minutes. Real-time PCR detection and quantification of FOXO3a, RUNX2 and HPRT reference gene control were performed using SYBR Premix Ex Taq II (Tli RNaseH Plus), ROX plus (Takara, Japan) and specific reverse and forward primers (https://isdv.upv.cz/webapp/ webapp.pts.det?xprim $=10049277 \&$ lan $=$ cs\&s_majs $=\&$ s puvo $\left.=\& s \_n a z e=\& s \_a n o t=\right)$. qPCR was performed using BIOER, LineGene 9660 Real-Time PCR System (Hangzhou Bioer Technology Co., Ltd, China) at following settings: $95^{\circ} \mathrm{C}$ for $5 \mathrm{~min}$, followed by 40 cycles of $95^{\circ} \mathrm{C}$ for $20 \mathrm{sec}$ and $60^{\circ} \mathrm{C}$ for $50 \mathrm{sec}$, followed by melt cycle. All samples were amplified in triplicates. Ct values were averaged and normalized against reference endogenous control HPRT. Relative expression was determined by the $2^{-(\Delta \Delta C t)}$ comparative threshold method.

Statistical analysis. Data shown in graphs represent the mean values \pm SD. Group comparison and the significance of fold change in miRNA expression was analyzed by oneway ANOVA. Analyses were performed using GraphPad Prism v.5 (La Jolla, CA, USA) and STATISTICA 7 (StatSoft, CZ) software. Results with a $P$ value $<0.05$ were considered significant.

\section{Results}

Expression levels of selected miRNAs. qRT-PCR differential analysis of expression of selected miRNAs in PBMCs in individual groups of BC patients (groups 3 and 4) compared to healthy individuals (group 1) showed significantly increased expression levels of miR-17, miR-19a, miR-21, miR-27a and miR-155, while expression levels of miR-18a and miR-20a left unchanged or even slightly down-regulated (Figure 1). In our study, miR-19a was the only miRNA observed to be upregulated in individuals carrying $B R C A 1$ mutations with no disease manifestation (group 2). MiR-19a is a member of miR17 92 cluster and represents the most abundantly expressed miRNA triggering the expression of other members of this oncogenic cluster. Compared to healthy controls, where the level of miR-19a expression was $0.86 \pm 0.15$ a.u., $B R C A 1$ carriers with no disease manifestation displayed the miR-19a expression levels of $2.74 \pm 0.28$ a.u. ( $p<0.01)$. MiR-19a expression further increased in BRCA1 carriers with BC $(3.61 \pm 0.46$ a.u., $\mathrm{p}<0.001)$ and the highest levels of its expression were detected in acute $\mathrm{BC}$ patients $(4.78 \pm 0.61$ a.u., $\mathrm{p}<0.001)$. 


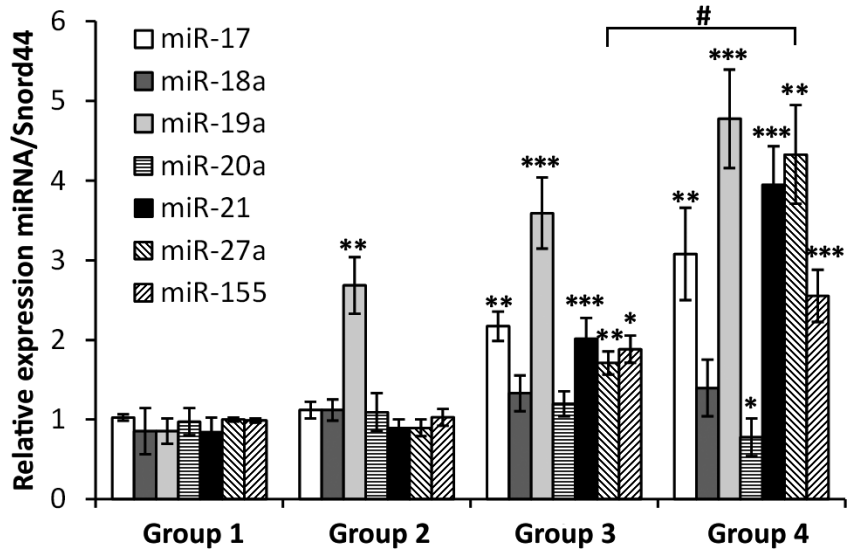

Figure 1. Real-time RT-PCR quantitation of the selected miRNAs. The expression of miR-17, miR-19a, miR-21, miR-27a and miR-155 was significantly up-regulated in all tested groups (group 2: $n=14,3$ replicates each; group 3: $n=10,3$ replicates each; group $4: n=30,3$ replicates each) compared to healthy controls (group 1: $n=13,3$ replicates each). On the other hand, miR-18a and miR-20a expression levels left unchanged in groups 2-3 (group 2: $\mathrm{n}=14,3$ replicates each; group 3:n=10, 3 replicates each) compared to healthy control. In group $4(n=30,3$ replicates each) miR-18a left unchanged and miR-20a was significantly down-regulated. All data were normalized against Snord44 reference gene expression control. Values represent mean $\pm \mathrm{SEM} ;{ }^{*}, \#<0.05,{ }^{* *} \mathrm{p}<0.01,{ }^{\star * *} \mathrm{p}<0.001$.

MiR-17, miR-21, miR-27a and miR-155 showed similar expressional profiles in all tested groups (Figure 1). None of these miRNAs was up-regulated in BRCA 1 carriers with no disease (miR-17: $1.12 \pm 0.11$ a.u., miR-21: $0.91 \pm 0.10$ a.u., miR-27a: $0.90 \pm 0.11$ a.u., miR-155: $1.02 \pm 0.06$ a.u.) and their expression levels were almost identical with healthy control (miR-17: $1.04 \pm 0.06$ a.u., miR-21: $0.84 \pm 0.20$ a.u., miR-27a: $1.02 \pm 0.05$ a.u., miR-155: 0. $96 \pm 0.05$ a.u.). Expression levels of these miRNAs significantly increased in BRCA1 carriers with BC (miR-17: 2.19 \pm 0.17 a.u., $\mathrm{p}<0.01$; miR-21: $2.01 \pm 0.25$ a.u., $\mathrm{p}<0.001$;
miR-27a: $1.71 \pm 0.14$ a.u., $\mathrm{p}<0.001$; miR-155: $1.92 \pm 0.13$ a.u., $\mathrm{p}<0.001$ ) and acute BC patients (miR-17: $3.16 \pm 0.25$ a.u., $\mathrm{p}<$ 0.01; miR-21: $3.96 \pm 0.48$ a.u., $\mathrm{p}<0.001$; miR-27a: $4.33 \pm 0.59$ a.u., p < 0. 01; miR-155: 2.56 \pm 0.31 a.u., p<0.001). Substantial increase of expression of miR-21, miR-27a and miR-155 was observed also in acute $\mathrm{BC}$ patients compared to BRCA1 carriers with $\mathrm{BC}(\mathrm{p}<0.05)$.

MiR-18a and miR-20a as members of oncogenic cluster miR-17 92 showed a unique pattern of expression profiles in individual groups. The expression levels of miR-18a in groups $2-4$ were $1.12 \pm 0.12,1.33 \pm 0.21$ and $1.41 \pm 0.38$ a.u. respectively, and these values were comparable with those of healthy control ( $0.87 \pm 0.13$ a.u.), suggesting that miR-18a expression level is not affected by BRCA1 status, therapy process/outcome and disease stage. In a similar manner, miR-20a expression levels were almost unchanged in groups 2-3 compared to healthy control (0.98 \pm 0.15 a.u.), but in acute BC patients they were down-regulated $(0.78 \pm 0.13$ a.u.), indicating tumor suppressive role of this miRNA. In line with this assumption, tumor resection and subsequent therapy restored normal levels of miR-20a (1.22 \pm 0.14 a.u., p < 0. 05) (Figure 1).

Expression levels of FOXO3a. To further explain and confirm the regulatory role of these oncogenic miRNAs in $\mathrm{BC}$, we have evaluated the expression levels of the FOXO3a and RUNX2 genes that are both known to be regulated by the studied miRNAs [17, 20, 24, 26]. qRT-PCR analysis of mRNA expression of FOXO3a in PBMCs showed, that compared to healthy control ( $4.11 \pm 0.42$ a.u.), FOXO3a expression significantly decreased in all tested groups to approximately the same level (Figure 2A). These results suggest that selected oncogenic miRNAs could post-transcriptionally suppress the expression of FOXO3a mRNA due to complementary binding to its 3'UTR region. Consequently, expression of FOXO3a mRNA was correlated with that of the oncogenic miRNAs, miR-17, miR-19a, miR-21, miR-27a and miR-155. Indeed, negative correlation between expression of FOXO3a and se-
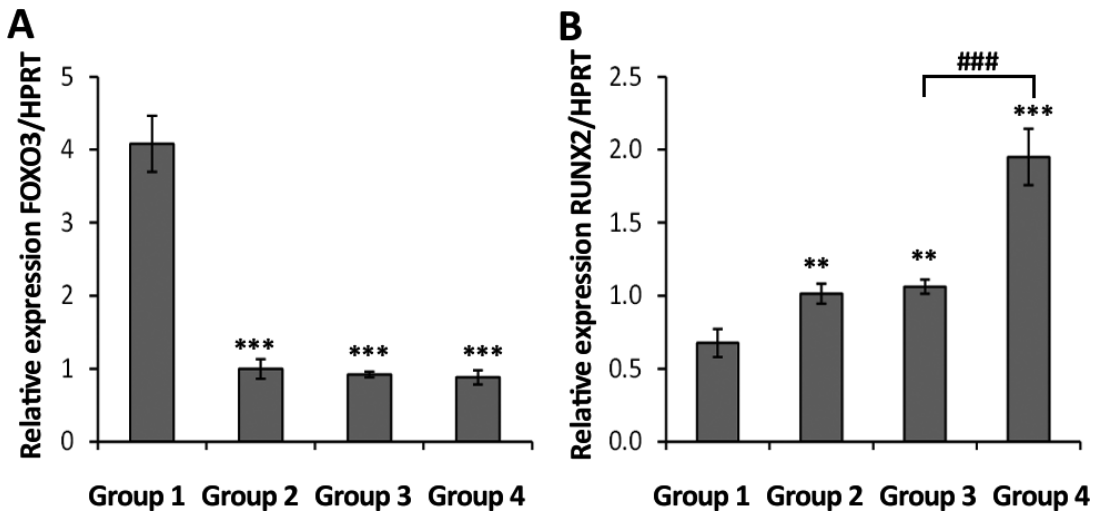

Figure 2. Real-time RT-PCR quantitation of expression of the two target genes, FOXO3a and RUNX2. (A) qRT-PCR analysis of mRNA expression of FOXO3a showed significant decrease in all tested groups of patients 2-4 in comparison to healthy control. (B) In contrary, the expression levels of RUNX2 were significantly up-regulated in groups 2-4 compared to healthy control. Significant increase of RUNX2 expression was also observed in group 4 compared to group 3. All data were normalized against HPRT reference gene expression. Values represent mean $\pm \operatorname{SEM} ;{ }^{* *} \mathrm{p}<0.01,{ }^{\star * *}, \# \# \#<0.001$. 

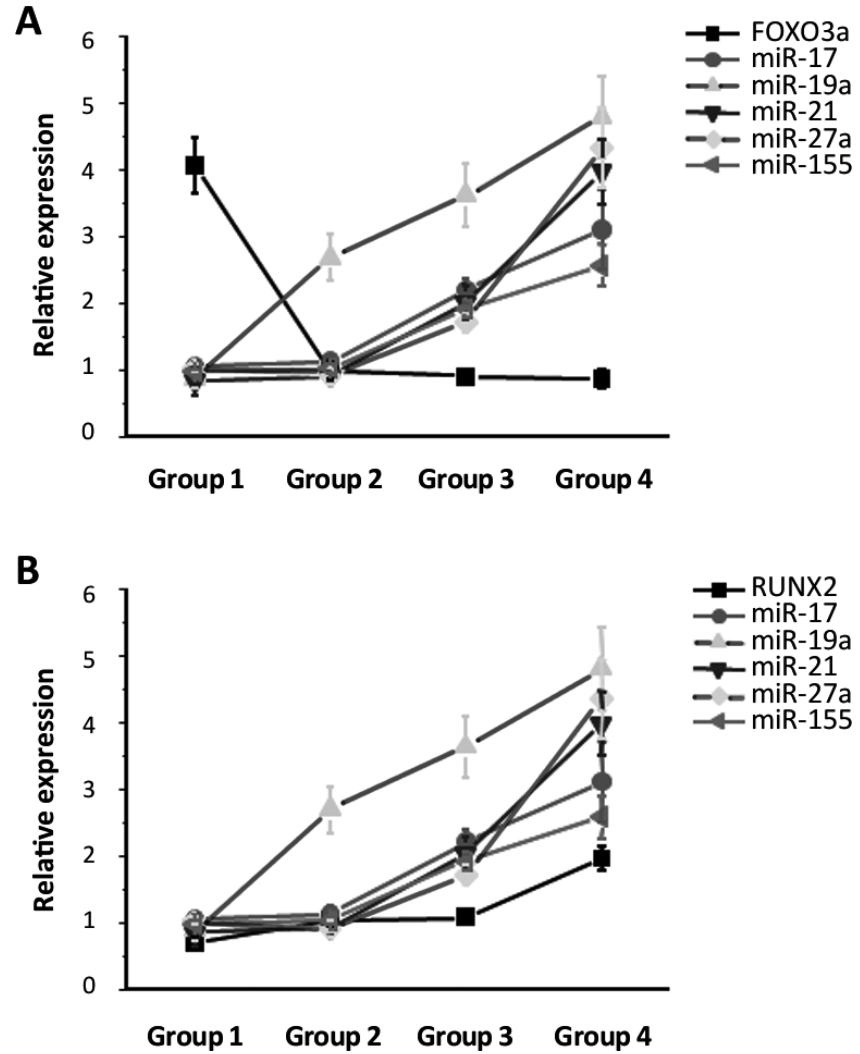

Figure 3. Expression profile correlation of oncogenic miRNAs with FOXO3a and RUNX2. The expression correlation of FOXO3a mRNA (A) with oncogenic miRNAs, miR-17, miR-19a, miR-21, miR-27a and miR-155 revealed their negative correlation, while the expression of RUNX2 mRNA (B) was up-regulated in a similar manner to all oncogenic miRNAs. Values represent mean \pm SEM.

lected oncogenic miRNAs was revealed (Figure 3A). On the other hand, it appears that FOXO3a expression is not subject to regulation by miR-18a and miR-20a (Figure 4A).

Expression levels of RUNX2. In opposite, the expression levels of RUNX2 in PBMCs were significantly up-regulated in groups 2-4 compared to healthy control. While RUNX2 expression levels in healthy control reached values of $0.69 \pm 0.10$ a.u., in a group of $B R C A 1$ carriers with no disease manifestation they were $1.01 \pm 0.07$ a.u., $\mathrm{p}<0.01$. Very similar pattern of RUNX2 expression increase was observed in BRCA1 carriers with BC (1.07 \pm 0.06 a.u., $\mathrm{p}<0.01)$; however, a highly significant increase of RUNX2 expression level was observed in group of acute BC patients $(1.95 \pm 0.17$ a.u., $\mathrm{p}<0.001)$. Difference in RUNX2 expression between groups 3 and 4 was also significant $(\mathrm{p}<0.001)$ (Figure $2 \mathrm{~B})$, suggesting that tumor resection and therapy suppressed high expression of this oncogenic transcription factor. In accordance with the situation for FOXO3a, the expression of RUNX2 mRNA positively correlates with that of the oncogenic miRNAs (miR-17, miR-19a, miR-21, miR-27a and miR-155) (Figure 3B) and, in general, is not under the control of miR-18a or miR-20a (Figure 4B).
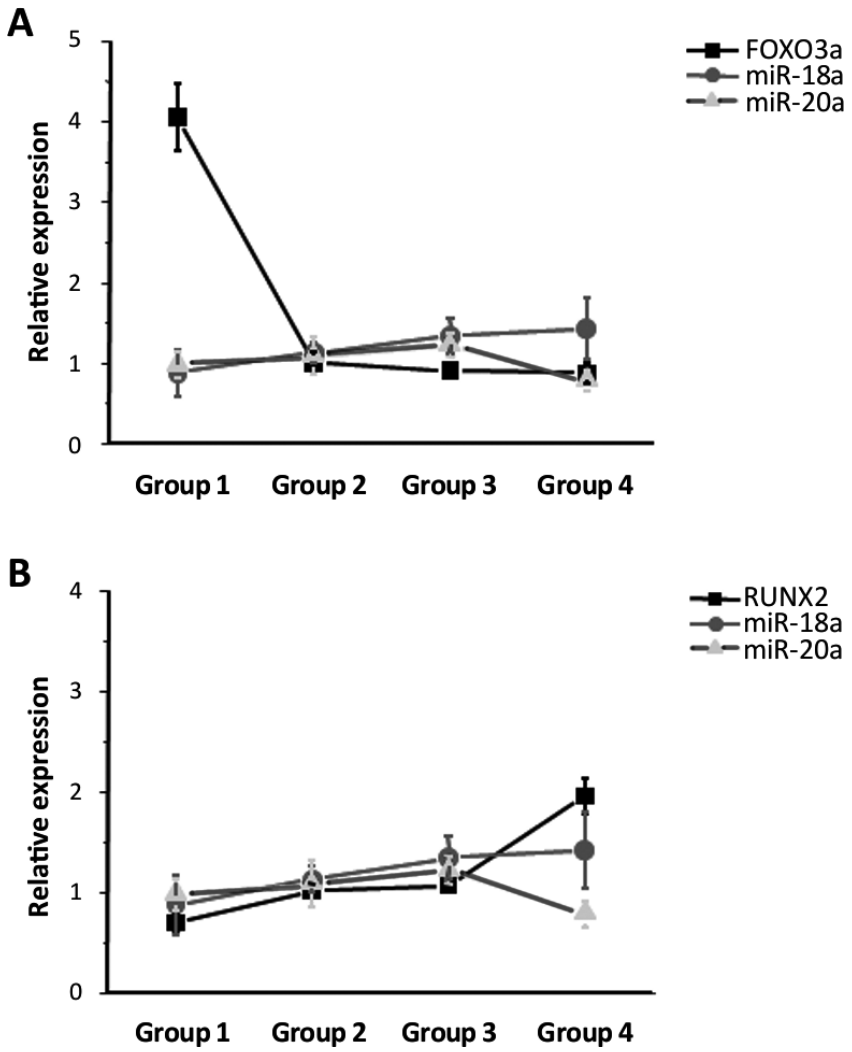

Figure 4. Expression profile correlation of suppressor miRNAs with FOXO3a and RUNX2. Down-regulation of FOXO3a (A) expression correlated with unchanged or even decreased expression of miR-18a and miR-20a. On the other hand, the expression of RUNX2 (B) followed the up-regulated expression of oncogenic miRNAs and was increased in miR-18a/miR-20a-independent manner. Values represent mean \pm SEM.

\section{Discussion}

There has been an extensive research focused on identification and clinical validation of novel molecular biomarkers that would enable early recognition, diagnostics and prediction of BC. Novel molecular diagnostic tests dealing with personalized information allow specific treatment plans recognizing resistance, non-response, and treatment toxicity. PBMCs act as the first line of defense against malignancy in immune system, their dysfunction may occur as an early event in cancer immunogenicity or immune evasion [29]. Therefore, the analysis of miRNAs and their expressional profiles in PBMCs could provide supplementary information to conventional diagnostics and may contribute to improved decision making process for diagnostic and therapeutic approaches [30, 31].

Our study shows that expression profile of miR-17, miR19a, miR-21, miR-27a and miR-155 can distinguish BC patients from healthy individuals, reflect $B C$ patients' therapy outcome, as well as distinguishes $B R C A 1$ mutation carriers with manifested disease from those with no disease manifestation. To further support informative value of miRNA 
expression profiling for potential diagnostic purposes, we followed their regulatory roles and evaluated the effect of selected miRNAs on expression of the two key target BC genes, FOXO3a and RUNX2.

We compared miRNA and target genes' expression profiles of acute BC patients and BRCA1 mutation carriers with and without disease manifestation against healthy control. In acute $\mathrm{BC}$ patients and $B R C A 1$ carriers with $\mathrm{BC}$, we observed significant up-regulation of oncogenic miR-17, miR-19a, miR21, miR-27a and miR-155, while expression of miR-18a and miR-20a, also members of miR-17 92 cluster, left unchanged, or even down-regulated, pointing to their tumor suppressor role in BC. Interestingly, miR-19a expression increased not only during the transition from no observable to obvious disease state in the BRCA1 mutation carriers, but it was higher even in BRCA1 mutation carriers with no disease manifestation compared to healthy control (very likely non-mutation carriers), indicating that impaired BRCA1 function leads to aberrant miR-19a production. Such miR-19a expressional change could be one of the factors that are responsible for epithelial and stromal changes observed in the asymptomatic breast of BRCA1 germline mutation carriers [32].

Published data on expression of indiviual members of miR-17 92 cluster in BC are not uniform. Our observation of increased expression of miR-17 and miR-19a was in correlation with findings by Calvano Filho and co-workers [33] who observed overexpression of miR-17 92 cluster in triple-negative $\mathrm{BC}$ on one side, but up-regulation of miR$18 \mathrm{a}$ and miR-20a on the other. Previous studies suggested that miR-17 is highly expressed in the aggressive $\mathrm{BC}$ cell line MDA-MB-231, but not in the less invasive MCF-7 cell line. Zuoren et al. reported that miR-17/20 abundance is reduced in highly invasive $\mathrm{BC}$ cell lines and node-positive $\mathrm{BC}$ specimens [34]. MiR-18a was observed to be overexpressed in tumors compared with normal breast tissues and in triplenegative compared with luminal A tumors [35]. These data suggest that miR-18a may function as an oncogene. However, other studies reported that miR-18a was overexpressed in ER-negative breast tissues, suggesting that it may have a role as tumor suppressor [35]. It is obvious that members of this cluster may function as both oncogenes and tumor suppressors [36].

Up-regulation of miR-17 92 cluster has been observed in multiple tumor types, including BC. Regarding the mechanism, miR-17 92 cluster post-transcriptionally inhibits E2F and Myc. In return, E2F and Myc induce the transcription of miR-17 92, thus forming a negative feedback loop in the interaction network. The E2F family of transcription factors and Myc critically regulate cell-cycle and apoptosis [37-39]. On the other hand, pro-apoptotic gene BCL2L11/BIM has been reported to be a direct target of multiple members of the miR-17 92 cluster in BC [40]. The pro-tumorigenic activity of the miR-17 92 cluster additionally involves cell non-autonomous functions including induction of angiogenesis in solid tumors [41].
MiR-17 92 is transactivated by Myc in an ER-alphadependent manner. Because miR-17 targets BRCA1, this regulation suggests a mechanism by which the oncogene $\mathrm{Myc}$ may repress tumor-supressor BRCA1 [42]. Approximately 10\% of patients diagnosed with $\mathrm{BC}$ harbor a mutation in genes encoding BC susceptibility protein $1 / 2$ (BRCA1/2). Familial history of cancer explains only $10 \%-37 \%$ of the cases, of which $10 \%-25 \%$ were attributable to $B R C A 1 / 2$ mutations, currently known as the two major BC predisposing genes $[43,44]$. In sporadic cases, this frequency is remarkably lower, ranging from $3 \%-10 \%$ [45]. Women who carry such mutations are at increased risk of developing breast and ovarian cancers [46-50]. BC associated with BRCA1 mutations often have aggressive characteristics including presentation at a younger age, poor differentiation, and high proliferation rate. They are also more likely to be ER-negative [46-50].

Another cross-talk between BRCA1 and miRNA network is mediated by miR-155, as it has been shown that BRCA $1 \mathrm{ab}$ rogates the repression of miR-155 [15]. BRCA1 is recruited to MIR155HG promoter where it contains two putative binding sites, leading to repression of activity of this promoter. Importantly, cells expressing functional BRCA1 treated with HDAC inhibitors up-regulate the expression of miR-155, suggesting that BRCA1 epigenetically represses miR- 155 expression via its association with HDAC2, which deacetylates histones $\mathrm{H} 2 \mathrm{~A}$ and $\mathrm{H} 3$ in the MIR155HG promoter. In addition, we show that BRCA1 regulates the miR-19a levels (Figure 1). Together, this suggests that a strong BRCA1-miRNA regulatory network operates in $\mathrm{BC}$ tumorigenesis and that a proportion of BRCA1 functions in a cell is mediated epigenetically via miRNA molecules.

MiR-155 is significantly up-regulated in BC and positively correlates with high tumor grade, progressive stage and metastases to lymph nodes, whereas it inversely correlates with overall and disease-free survival [51]. MiR-155 suppresses the functions of several tumor repressors. Pro-oncogenic environment in tumors, including hypoxia and inflammation, trigger its expression. MiR-155 expression is promoted by TGF- $\beta$ through the direct activity of Smad 4 transcription factor, contributing to epithelial-mesenchymal transition, cancer cell migration and invasion [52]. In many BC cancer cell lines, expression of miR-155 is also promoted by factors that induce tumor inflammation, like interleukin (IL)-6 and interferon (IFN) $-\gamma$. MiR-155 prevents SOCS1 and stimulates activity of the JAK2/STAT3 pathway, which leads to tumor growth [53]. Overexpression of miR-155 accelerates whereas the knockdown of miR-155 attenuates the growth of tumor cell lines in vivo. The mature miR- 155 prevents the translation of miR-155 target mRNAs in BC, including RhoA, FOXO3a and SOCS1 [54].

Pro-apoptotic transcription factor FOXO3a is a critical target of miR-155 [55]. A negative correlation between miR-155 and FOXO3a in multiple BC cell lines and tumors has been well-documented [56,57]. Our data on expression profiles of FOXO3a in BC patients are in correlation with published data. 
The expression of FOXO3a negatively correlated with expression profiles of oncogenic miRNAs.

FOXO3a participates in many physiological processes and is a critical regulator of cell survival and proliferation. Several reports have demonstrated in breast cancer MCF7 cells, the ability of chemotherapeutic drugs to induce FOXO3a activation (i.e. accumulation of FOXO3a in the nucleus) $[58,59]$. FOXO3a activation results in an increase in pro-apoptotic protein expression and provides a mechanism promoting apoptosis in breast and other cancer cells $[60,61]$. The steroid hormone estrogen facilitates progression of hormone-sensitive tumors, including breast cancer, through its classical nuclear receptors by transcriptional regulation resulting in cell survival and proliferation [62]. However, estrogen also mediates rapid signaling and growth effects through an additional estrogen receptor, GPER $[63,64]$. These signaling events include the activation of MAPKs [65], as well as activation of the PI3Kinase pathway $[66,67]$. It has been established that PI3Kinase activation by growth factor receptors in general can stimulate Akt to phosphorylate and inactivate FOXO3a, thereby excluding it from the nucleus, leading to its degradation, and the downregulation of pro-apoptotic gene expression [68].

It is widely recognized that $\mathrm{BC}$ cells preferentially metastasize to bones $[69,70]$. MiR-155 directly targets RUNX2 $[71,72]$, a trascription factor associated with osteogenesis, as well as BC-mediated bone metastasis [69]. Our results show positive correlation of RUNX2 expression with all oncogenic miRNAs tested but not with miR-18a and miR-20a.

RUNX2 is expressed in mammary epithelial cells during development at low levels, but has been found to be expressed at high levels in metastatic BC cells $[73,74]$. RUNX2 activates cancer related genes in response to deregulated cell signaling pathways during early stages of BC. Inhibition of RUNX2 activity abolishes the ability of $\mathrm{BC}$ cells to form osteolytic lesions in vivo [69]. RUNX2 was identified as one of the most up-regulated genes in a comparative screen of invasive versus non-invasive BC cell lines [75]. It has been shown to control the expression of genes associated with tumor cell migration, metastasis and angiogenesis, such as bone sialoprotein, osteopontin, matrix metalloproteinases (MMPs), vascular endothelial growth factor (VEGF) and collagenase-3 [76, 25, 77].

In line with other authors, we observed significantly upregulated expression of miR-21 in BRCA1 mutation carriers with $\mathrm{BC}$, as well as in acute $\mathrm{BC}$ patients. Overexpression of miR-21 was observed in glioblastoma [78], lung [79], prostate [80], colon [81], cervical and breast cancers [82-84]. Up-regulation of miR-21 in primary BC samples has been shown to be associated with the advanced clinical stage, lymph node metastasis and poor prognosis [85]. MiR-21 can target a number of tumor-suppressor genes, supporting its oncogenic role in vast majority of cancer types. The tumor suppressor gene TPM1 (tropomyosin-1) in BC is considered as direct target of miR21 [86]. Some tumor suppressors such as p53, PDCD4, and maspin are other miR-21 targets in BC [87].
In line with data by others, we also detected up-regulated miR-27a expression in BC patients. MiR-27a appears to target the transcriptional co-factor, zinc finger and $\mathrm{BTB}$ domain containing 10 (ZBTB10) [88]. ZBTB10 represses the specificity protein 1 (SP1) transcription factor. The SP1 transcription factor is overexpressed in many cancers and plays a role in the G0-G1 to $S$ phase progression in $B C$ cells [89]. If expression of ZBTB10 is reduced, miR-27a indirectly up-regulates $\mathrm{SP} 1$, thus increasing $\mathrm{S}$ phase progression, and functions as an oncogene. MiR-27a can regulate E2-responsiveness in MCF-7 cells through suppression of ZBTB10, thereby enhancing expression of ER [88]. MiR-27a was shown to suppress the $\mathrm{cdc} 2 / \mathrm{cyclin} \mathrm{B}$ inhibitor Myt-1 in MDA-MB-231 cells and facilitate BC cell proliferation. Thus, the oncogenic activity of miR-27a in MDA-MB-231 cells was due to suppression of expression of ZBTB10 and Myt-1 proteins [89]. FOXO3a has been shown as direct target of miR-27a in glioblastoma cells [90].

Our results show that expression profiles of oncogenic miRNAs, miR-17, miR-19a, miR-21, miR-27a and miR-155, are associated with increased expression of RUNX2 and, in parallel, down-regulation of FOXO3a in BC patients. Opposite expression pattern was observed for miR-18a and miR-20a. Clinical and laboratory correlative analyses indicate that BC patients with higher expression of RUNX2 and low expression of FOXO3a tend to develop metastasis and suffer from a greater risk of disease recurrence or death $[91,92]$. Therefore, the expression levels of miR-155, miR-17 92 cluster, miR-21 and miR-27a, as well as of two their targets (FOXO3a and RUNX2), could provide an additional improvement for development of screening and early diagnostic strategies and could be considered as valuable supportive markers for diagnostics and prediction of $\mathrm{BC}$ patients. We suggest that expression profiles of miR-17, miR-19a, miR-21, miR-27a, miR-155 and RUNX2 could be used as biomarkers of therapy outcome in BC patients. In addition, it seems that miR-19a, FOXO3a and RUNX2 expression levels could be able to reflect very early molecular changes in normal breast tissue of $B R C A 1$ mutation carriers before observable morphological changes at cellular levels occur. Finally, information on miR-19a and FOXO3a expression levels along with molecular characterization of BRCA1 germline mutation in BRCA1 carriers with no disease manifestation could stratify them mainly in terms of disease onset. Further work on more extensive number of patients is required to confirm and address these possibilities in more detail.

Acknowledgements: This work was supported by grant co-sponsored by sources of EU - European fund for regional development through operation program of Research and Development (project code ITMS 26240220074/call code OPVaV-2011/4.2/07-SORO). We would like to greatly acknowledge personnel of University Hospital of Medical Faculty, Comenius University and National Cancer Institute in Bratislava, Slovakia for their contribution and help with patients ' samples collection and management. 


\section{References}

[1] VIMALRAJ S, MIRANDA PJ, RAMYAKRISHNA B, SELVAMURUGAN N. Regulation of breast cancer and bone metastasis by microRNAs. Dis Markers 2013; 35: 369-87. http://dx.doi.org/10.1155/2013/451248

[2] TAYLOR S, LAM M, PARARASA C, BROWN JE, CARMICHAEL AR et al. Evaluating the evidence for targeting FOXO3a in breast cancer: a systematic review. Cancer Cell Int 2015 24; 15:1.

[3] FERRARI N, MOHAMMED ZM, NIXON C, MASON SM, MALLON E et al. Expression of RUNX1 correlates with poor patient prognosis in triple negative breast cancer. PLoS One 2014; 9: e100759. http://dx.doi.org/10.1371/journal. pone.0100759

[4] DUFFY MJ. Serum tumor markers in breast cancer: are they of clinical value? Clin Chem 2006; 52: 345-351. http://dx.doi. org/10.1373/clinchem.2005.059832

[5] DALAMAGA M, ARCHONDAKIS S, SOTIROPOULOS G, KARMANIOLAS K, PELEKANOS N et al. Could serum visfatin be a potential biomarker for postmenopausal breast cancer? Maturitas 2012; 71: 301-308. http://dx.doi. org/10.1016/i.maturitas.2011.12.013

[6] BARTEL DP. MicroRNAs: genomics, biogenesis, mechanism, and function. Cell 2004; 116: 281-297. http://dx.doi. org/10.1016/S0092-8674(04)00045-5

[7] TURCHINOVICH A, SAMATOV TR, TONEVITSKY AG, BURWINKEL B. Circulating miRNAs: cell-cell communication function? Front Genet 2013; 4: 119. http://dx.doi. org/10.3389/fgene.2013.00119

[8] CORTEZ MA, WELSH JW, CALIN GA. Circulating microRNAs as noninvasive biomarkers in breast cancer. Recent Results Cancer Res 2012; 195: 151-161. http://dx.doi.org/10.1007/9783-642-28160-0 13

[9] FARAZI TA, HORLINGS HM, TEN HOEVE JJ, MIHAILOVIC A, HALFWERK $\mathrm{H}$ et al. MicroRNA sequence and expression analysis in breast tumors by deep sequencing. Cancer Res 2011; 71: 4443-4453. http://dx.doi. org/10.1158/0008-5472.CAN-11-0608

[10] VOLINIA S, GALASSO M, SANA ME, WISE TF, PALATINI $J$ et al. Breast cancer signatures for invasiveness and prognosis defined by deep sequencing of microRNA. Proc Natl Acad Sci 2012; 109: 3024-3029. http://dx.doi.org/10.1073/ pnas. 1200010109

[11] GAO Y, CAI Q, HUANG Y, LI S, YANG H et al. MicroRNA-21 as a potential diagnostic biomarker for breast cancer patients: a pooled analysis of individual studies. Oncotarget 2016; 7: 23.

[12] ZHOU S, HUANG Q, ZHENG S, LIN K, YOU J et al. miR27 a regulates the sensitivity of breast cancer cells to cisplatin treatment via BAK-SMAC/DIABLO-XIAP axis. Tumour Biol 2016; 37: 6837-6845. http://dx.doi.org/10.1007/s13277-015$\underline{4500-1}$

[13] JURKOVICOVA D, MAGYERKOVA M, KULCSAR L, KRIVJANSKA M, KRIVJANSKY V et al. miR-155 as a diagnostic and prognostic marker in hematological and solid malignancies. Neoplasma 2014; 61:241-251. http://dx.doi.org/10.4149/ neo 2014032
[14] JURKOVICOVA D, LUKACKOVA R, MAGYERKOVA M, KULCSAR L, KRIVJANSKA $M$ et al. microRNA expression profiling as supportive diagnostic and therapy prediction tool in chronic myeloid leukemia. Neoplasma.2015; 62: 949-958. http://dx.doi.org/10.4149/neo $2015 \quad 115$

[15] CHANG S, SHARAN SK. Epigenetic control of an oncogenic microRNA, miR-155, by BRCA1. Oncotarget 2012; 3 : $5-6$.

[16] CHANG S, SHARAN SK. The role of epigenetic transcriptional regulation in BRCA1-mediated tumor suppression. Transcription 2013; 4: 24-28. http://dx.doi.org/10.4161/ $\underline{\operatorname{trns} .22600}$

[17] MONSALVE M, OLMOS Y. The complex biology of FOXO. Curr Drug Targets 2011; 12: 1322-1350. http://dx.doi. org/10.2174/138945011796150307

[18] HUANG H, TINDALL DJ. Dynamic FoxO transcription factors. J Cell Sci 2007; 120: 2479-2487. http://dx.doi. org/10.1242/jcs.001222

[19] YANG JY, ZONG CS, XIA W, YAMAGUCHI H, DING Q et al. ERK promotes tumorigenesis by inhibiting FOXO3a via MDM2-mediated degradation. Nat Cell Biol 2008; 10: 138-148. http://dx.doi.org/10.1038/ncb1676

[20] HU MC, LEE DF, XIA W, GOLFMAN LS, OU-YANG F et al. IkappaB kinase promotes tumorigenesis through inhibition of forkhead FOXO3a. Cell 2004; 117: 225-237. http://dx.doi. org/10.1016/S0092-8674(04)00302-2

[21] WANG K, LI PF. FOXO3a regulates apoptosis by negatively targeting miR-21. J Biol Chem 2010; 285: 16958-16966. http:// dx.doi.org/10.1074/jbc.M109.093005

[22] GE YF, SUN J, JIN CJ, CAO BQ, JIANG ZF et al. AntagomiR27a targets FOXO3a in glioblastoma and suppresses U87 cell growth in vitro and in vivo. Asian Pac J Cancer Prev 2013; 14: 963-968. http://dx.doi.org/10.7314/APJCP.2013.14.2.963

[23] DUCY P, ZHANG R, GEOFFROY V, RIDALL AL, KARSENTY G. Osf2/Cbfa1: a transcriptional activator of osteoblast differentiation. Cell 1997; 89: 747-754. http:// dx.doi.org/10.1016/S0092-8674(00)80257-3

[24] KOMORI T. Runx2, a multifunctional transcription factor in skeletal development. J Cell Biochem 2002; 87:1-8. http:// dx.doi.org/10.1002/jcb.10276

[25] INMAN CK, SHORE P. The osteoblast transcription factor Runx2 is expressed in mammary epithelial cells and mediates osteopontin expression. J Biol Chem 2003; 278: 48684-48689. http://dx.doi.org/10.1074/jbc.M308001200

[26] ONODERA Y, MIKI Y, SUZUKI T, TAKAGI K, AKAHIRA J et al. Runx2 in human breast carcinoma: its potential roles in cancer progression. Cancer Sci 2010, 101: 2670-2675. http:// dx.doi.org/10.1111/j.1349-7006.2010.01742.x

[27] MACHACKOVA E, FORETOVA L, LUKESOVA M, VASICKOVA P, NAVRATILOVA $M$ et al. Spectrum and characterisation of BRCA1 and BRCA2 deleterious mutations in high-risk Czech patients with breast and/or ovarian cancer. BMC Cancer 2008; 8: 140. http://dx.doi.org/10.1186/1471$\underline{2407-8-140}$

[28] Breast Cancer Information Core Database http://research. nhgri.nih.gov/bic/ 
[29] MA J, LIN Y, ZHAN M, MANN DL, STASS SA et al. Differential miRNA expressions in peripheral blood mononuclear cells for diagnosis of lung cancer. Lab Invest 2015; 95: 1197-1206. http://dx.doi.org/10.1038/labinvest.2015.88

[30] MISHRA S, SRIVASTAVA AK, SUMAN S, KUMAR V, SHUKLA Y. Circulating miRNAs revealed as surrogate molecular signatures for the early detection of breast cancer. Cancer Lett 2015; 369: 67-75. http://dx.doi.org/10.1016/j. canlet.2015.07.045

[31] CHANG CW, WU HC, TERRY MB, SANTELLA RM. microRNA Expression in Prospectively Collected Blood as a Potential Biomarker of Breast Cancer Risk in the BCFR. Anticancer Res 2015; 35: 3969-3977.

[32] WEBER F, SHEN L, FUKINO K, PATOCS A, MUTTER GL et al. Total-genome analysis of BRCA1/2-related invasive carcinomas of the breast identifies tumor stroma as potential landscaper for neoplastic initiation. Am J Hum Genet 2006; 78: 961-72. http://dx.doi.org/10.1086/504090

[33] CALVANO FILHO CM1, CALVANO-MENDES DC, CARVALHO KC, MACIEL GA, RICCI MD et al. Triple-negative and luminal A breast tumors: differential expression of miR18a-5p, miR-17-5p, and miR-20a-5p. Tumour Biol 2014; 35: 7733-7741. http://dx.doi.org/10.1007/s13277-014-2025-7

[34] ZUOREN Y, NICOLE EW, JIE Z, SANJAY K, MIN W et al. microRNA 17/20 inhibits cellular invasion and tumor metastasis in breast cancer by heterotypic signaling. PNAS 2010; 107: 8231. http://dx.doi.org/10.1073/pnas.1002080107

[35] GUO X, YANG C, QIAN X, LEI T, LI Y et al. Estrogen receptor regulates ATM expression through miRNAs in breast cancer. Clin Cancer Res 2013; 19: 4994-5002. http://dx.doi. org/10.1158/1078-0432.CCR-12-3700

[36] ZHANG ZW, AN Y, TENG CB. The roles of miR-17-92 cluster in mammal development and tumorigenesis. Yi Chuan 2009; 31: 1094-1100. http://dx.doi.org/10.3724/ SP.J.1005.2009.01094

[37] O`DONNELL KA, WENTZEL EA, ZELLER KI, DANG CV, MENDELL JT. c-Myc-regulated microRNAs modulate E2F1 expression. Nature 2005; 435: 839-843. http://dx.doi. org/10.1038/nature03677

[38] XIANG J, WU J. Feud or friend? The role of the miR-17-92 cluster in tumorigenesis. Curr Genomics 20101; 11: 129-135. http://dx.doi.org/10.2174/138920210790886853

[39] AGUDA BD, KIM Y, PIPER-HUNTER MG, FRIEDMAN A, MARSH CB. MicroRNA regulation of a cancer network: consequences of the feedback loops involving miR-17-92, E2F, and Myc. Proc Natl Acad Sci USA 2008; 105: 19678-19683. http://dx.doi.org/10.1073/pnas.0811166106

[40] INOMATA M, TAGAWA H, GUO YM, KAMEOKA Y, TAKAHASHI N et al. MicroRNA-17-92 down-regulates expression of dis- tinct targets in different B-cell lymphoma subtypes. Blood 2009; 113: 396-402. http://dx.doi. org/10.1182/blood-2008-07-163907

[41] KUHNERT F, KUO CJ. miR-17-92 angiogenesis micromanagement. Blood 2010; 115: 4631-4633. http://dx.doi. org/10.1182/blood-2010-03-276428

[42] CASTELlANO L, GIAMAS G, JACOB J, COOMBES RC, LUCCHESI W et al.The estrogen receptor- $\alpha$-induced micro-
RNA signature regulates itself and its transcriptional response. Proc Natl Acad Sci USA 2009; 106: 15732-15737. http:// dx.doi.org/10.1073/pnas.0906947106

[43] FACKENTHAL JD, OLOPADE OI. Breast cancer risk associated with BRCA1 and BRCA2 in diverse populations. Nat Rev Cancer 2007; 7: 937-948. http://dx.doi.org/10.1038/nrc2054

[44] HAFFTY BG, CHOI DH, GOYAL S, SILBER A, RANIERI $\mathrm{K}$ et al. Breast cancer in young women (YBC): prevalence of BRCA1/2 mutations and risk of secondary malignancies across diverse racial groups. Ann Oncol 2009; 20: 1653-1659. http://dx.doi.org/10.1093/annonc/mdp051

[45] DE SANJOSE S, LEONE M, BEREZ V, IZQUIERDO A, FONT R et al. Prevalence of BRCA1 and BRCA2 germline mutations in young breast cancer patients: a populationbased study. Int J Cancer 2003; 106: 588-593. http://dx.doi. org/10.1002/ijc.11271

[46] FORD D, EASTON DF, BISHOP DT NAROD SA, GOLDGAR DE. Risks of cancer in BRCA1-mutation carriers. Breast cancer linkage consortium. Lancet 1994; 343: 692-695. http:// dx.doi.org/10.1016/S0140-6736(94)91578-4

[47] Easton D, Thompson D, Mcguffog L, Haites N, Schofield A et al. Cancer risks in BRCA2 mutation carriers. Breast cancer linkage consortium. J Natl Cancer Inst 1999; 91: 1310-1316. http://dx.doi.org/10.1093/jnci/91.15.1310

[48] THOMPSON D, EASTON DF. Cancer incidence in BRCA1mutation carriers. J Natl Cancer Inst 2002; 94: 1358-1365. http://dx.doi.org/10.1093/jnci/94.18.1358

[49] ANTONIOU A, PHAROAH PD, NAROD SRISCH, HA, EYFJORD JE et al. Average risks of breast and ovarian cancer associated with BRCA1 or BRCA2 mutations detected in case series unselected for family history: a combined analysis of 22 studies. Am J Hum Genet 2003; 72: 1117-1130. http://dx.doi. org/10.1086/375033

[50] BEGG CB, HAILE RW, BORG A, MALONE KE, CONCANNON P et al. Variation of breast cancer risk among BRCA1/2 carriers. JAMA 2008; 299: 194-201. http://dx.doi.org/10.1001/ jama.2007.55-a

[51] CHEN J, WANG BC, TANG JH. Clinical significance of MicoRNA-155 expression in human breast cancer. J Surg Oncol 2012; 106: 260-266. http://dx.doi.org/10.1002/jso.22153

[52] CZYZYK-KRZESKA M, ZHANG X. MiR-155 at the heart of oncogenic pathways. Oncogene 2014; 33: 677-678. http:// dx.doi.org/10.1038/onc.2013.26

[53] JIANG S, ZHANG HW, LU MH, HE XH, LI Y et al. MicroRNA-155 functions as an OncomiR in breast cancer by targeting the suppressor of cytokine signaling 1 gene. Cancer Res 2010; 70: 3119-3127. http://dx.doi.org/10.1158/0008-5472.CAN$\underline{09-4250}$

[54] MATTISKE S., SUETANI RJ, NEILSEN PM, CALLEN DF. The oncogenic role of miR-155 in breast cancer. Cancer Epidemiol Biomarkers Prev 2012; 21: 1236-1243. http://dx.doi. org/10.1158/1055-9965.EPI-12-0173

[55] KONG L HE M, COPPOLA J, GUO NN,, ESPOSITO D et al. MicroRNA-155 regulates cell survival, growth, and chemosensitivity by targeting FOXO3a in breast cancer. J Biol Chem 2010; 285: 17869-17879. http://dx.doi.org/10.1074/jbc. $\underline{\text { M110.101055 }}$ 
[56] TAYLOR S, LAM M, PARARASA C, BROWN JEP, CARMICHAEL AR et al. Evaluating the evidence for targeting FOXO3a in breast cancer: a systematic review. Cancer Cell Int 2015; 15: 1. http://dx.doi.org/10.1186/s12935-015-0156-6

[57] YAMAMOTO M, KONDO E, TAKEUCHI M, HARASHIMA A, OTANI T et al. miR-155, a Modulator of FOXO3a Protein Expression, Is Underexpressed and Cannot Be Upregulated by Stimulation of HOZOT, a Line of Multifunctional Treg. PLoS One 2011; 6: e16841. http://dx.doi.org/10.1371/journal. pone. 0016841

[58] HO KK, MCGUIRE VA, KOO CY, MUIR KW, DE OLANO N et al. Phosphorylation of FOXO3a on Ser-7 by p38 promotes its nuclear localization in response to doxorubicin. J Biol Chem 2012; 287: 1545-1555. http://dx.doi.org/10.1074/jbc. M111.284224

[59] SUNTERS A, MADUREIRA PA, POMERANZ KM, AUBERT M, BROSENS JJ et al. Paclitaxel-induced nuclear translocation of FOXO3a in breast cancer cells is mediated by c-Jun NH2-terminal kinase and Akt. Cancer Res 2006; 66: 212-220. http://dx.doi.org/10.1158/0008-5472.CAN-05$\underline{1997}$

[60] YANG JY, Hung MC. Deciphering the role of forkhead transcription factors in cancer therapy. Curr Drug Targets 2011; 12: 1284-1290. http://dx.doi.org/10.2174/138945011796150299

[61] SINGH A, PLATI J, KHOSRAVI-FAR R. Harnessing the tumor suppressor function of FOXO as an alternative therapeutic approach in cancer. Curr Drug Targets 2011; 12:1311-1321. http://dx.doi.org/10.2174/138945011796150271

[62] WILLIAMS C, LIN CY. Oestrogen receptors in breast cancer: basic mechanisms and clinical implications. Ecancermedicalscience 2013; 7: 370 .

[63] PROSSNITZER, BARTON M. Estrogen biology: new insights into GPER function and clinical opportunities. Mol Cell Endocrinol 2014; 389: 71-83. http://dx.doi.org/10.1016/j. mce.2014.02.002

[64] LAPPANO R, PISANO A, MAGGIOLINI M. GPER Function in Breast Cancer: An Overview. Front Endocrinol (Lausanne) 2014; 5: 66. http://dx.doi.org/10.3389/fendo.2014.00066

[65] FILARDO EJ, QUINN JA, BLAND KI, FRACKELTON AR Jr. Estrogen-induced activation of Erk-1 and Erk-2 requires the $G$ protein-coupled receptor homolog, GPR30, and occurs via trans-activation of the epidermal growth factor receptor through release of HB-EGF. Mol Endocrinol 2000; 14: 1649-1660. http://dx.doi.org/10.1210/mend.14.10.0532

[66] REVANKAR CM, CIMINO DF, SKLAR LA, ARTERBURN JB, PROSSNITZER. A transmembrane intracellular estrogen receptor mediates rapid cell signaling. Science 2005; 307: 1625-1630. http://dx.doi.org/10.1126/science.1106943

[67] SCALING AL, PROSSNITZ ER, HATHAWAY HJ. GPER mediates estrogen-induced signaling and proliferation in human breast epithelial cells and normal and malignant breast. Horm Cancer 2014; 5: 146-160. http://dx.doi.org/10.1007/ s12672-014-0174-1

[68] BRUNET A, BONNI A, ZIGMOND MJ, LIN MZ, JUO P et al. Akt promotes cell survival by phosphorylating and inhibiting a Forkhead transcription factor. Cell 1999 Mar 19; 96(6):857-68. http://dx.doi.org/10.1016/S0092-8674(00)80595-4
[69] YIN Q, WANG X, FEWELL C, CAMERON J, ZHU H et al. MicroRNA miR-155 inhibits Bone Morphogenetic Protein (BMP) signaling and BMP- mediated Epstein-Barr virus reactivation. J Virol 2010; 84: 6318-6327. http://dx.doi. org/10.1128/JVI.00635-10

[70] JAVED A, BARNES GL, PRATAPETAL J. Impairedintranuclear trafficking of Runx2 (AML3/CBFA1) transcription factors in breast cancer cells inhibits osteolysis in vivo. Proc Nat Acad Sci USA 2005; 102:1454-1459. http://dx.doi. org/10.1073/pnas.0409121102

[71] TOME M., P. LOPEZ-ROMERO, C. ALBO, SEPÚLVEDA JC, FERNÁNDEZ-GUTIÉRREZ B et al. MiR-335 orchestrates cell proliferation, migration and differentiation in human mesenchymal stem cells. Cell Death and Differentiation 2011; 18: 985-995. http://dx.doi.org/10.1038/cdd.2010.167

[72] HASSAN MQ, GORDON JA, BELOTI MM, CROCE CM, VAN WIJNEN AJ et al.Anetwork connecting Runx2, SATB2, and the miR-23a $\sim 27 \mathrm{a} \sim 24-2$ cluster regulates the osteoblast differentiation program. Proc Nat Acad Sci USA 2010; 107: 19879-19884. http://dx.doi.org/10.1073/ pnas. 1007698107

[73] PRATAP J, IMBALZANO KM, UNDERWOOD JM, COHET $\mathrm{N}, \mathrm{GOKUL} \mathrm{K}$ et al. Ectopic Runx2 expression in mammary epithelial cells disrupts formation of normal acini structure: implications for breast cancer progression. Cancer Res 2009; 69: 6807-6814. http://dx.doi.org/10.1158/0008-5472.CAN$\underline{09-1471}$

[74] DAS K, LEONG DT, GUPTA A, SHEN L, PUTTI T et al. Positive association between nuclear Runx2 and oestrogen-progesterone receptor gene expression characterises a biological subtype of breast cancer. Eur J Cancer 2009; 45: 2239-2248. http://dx.doi.org/10.1016/j.ejca.2009.06.021

[75] NAGARAJA GM, OTHMAN M, FOX BP, ALSABER R, PELLEGRINO CM et al. Gene expression signatures and biomarkers of noninvasive and invasive breast cancer cells: comprehensive profiles by representational difference analysis, microarrays and proteomics. Oncogene 2006; 25: 2328-2338. http://dx.doi.org/10.1038/sj.onc. 1209265

[76] BARNES CJ, KUMAR R. Epidermal growth factor receptor family tyrosine kinases as signal integrators and therapeutic targets. Cancer Metastasis Rev 2003; 22: 301-307. http:// dx.doi.org/10.1023/A:1023726827771

[77] SELVAMURUGAN N, KWOK S, ALLISTON T, REISS M, PARTRIDGE NC. Transforming growth factor-beta 1 regulation of collagenase- 3 expression in osteoblastic cells by cross-talk between the Smad and MAPK signaling pathways and their components, Smad 2 and Runx2. J Biol Chem 2004; 279: 19327-19334. http://dx.doi.org/10.1074/jbc. M314048200

[78] ANANTA JS, PAULMURUGAN R, MASSOUD TF. Tailored Nanoparticle Codelivery of antimiR-21 and antimiR-10b Augments Glioblastoma Cell Kill by Temozolomide: Toward a „Personalized“ Anti-microRNA Therapy. Mol Pharm 2016 Aug 19. [Epub ahead of print]

[79] RAZZAK R, BEDARD EL, KIM JO, GAZALA S, GUO L et al. MicroRNA expression profiling of sputum for the detection of early and locally advanced non-small-cell lung cancer: 
a prospective case-control study. Curr Oncol 2016; 23: e86-94. http://dx.doi.org/10.3747/co.23.2830

[80] RIBAS J, NI X, HAFFNER M, WENTZEL EA, SALMASI AH et al. miR-21: an androgen receptor-regulated microRNA that promotes hormone-dependent and hormone-independent prostate cancer growth. Cancer Res 2009; 69: 7165-7169. http://dx.doi.org/10.1158/0008-5472.CAN-09-1448

[81] ASANGANI IA, RASHEED SA, NIKOLOVA DA, LEUPOLD JH, COLBURN NH et al. MicroRNA-21 (miR-21) post-transcriptionally downregulates tumor suppressor Pdcd 4 and stimulates invasion, intravasation and metastasis in colorectal cancer. Oncogene 2008; 27: 2128-2136. http:// dx.doi.org/10.1038/sj.onc. 1210856

[82] APRELIKOVA O, YU X, PALLA J, WEI BR, JOHN S et al. The role of miR-31 and its target gene SATB2 in cancer-associated fibroblasts. Cell Cycle 2010; 9: 4387-4398. http://dx.doi. org/10.4161/cc.9.21.13674

[83] VOS S, VESUNA F, RAMAN V, VAN DIEST PJ, VAN DER GROEP P. miRNA expression patterns in normal breast tissue and invasive breast cancers of BRCA1 and BRCA2 germ-line mutation carriers. Oncotarget 2015; 6: 32115-32137.

[84] LIU Y, CAI Q, BAO PP, SU Y, CAI H et al. Tumor tissue microRNA expression in association with triple-negative breast cancer outcomes. Breast Cancer Res Treat 2015; 152: 183-191. http://dx.doi.org/10.1007/s10549-015-3460-x

[85] ROUAS R, FAYYAD-KAZAN H, EL ZEIN N, LEWALLE P, ROTHÉ F et al. Human natural Treg microRNA signature: role of microRNA-31 and microRNA-21 in FOXP3 expression. Eur J Immunol 2009; 39: 1608-1618. http://dx.doi. org/10.1002/eji.200838509

[86] CHRISTODOULATOS GS, DALAMAGA M. Micro-RNAs as clinical biomarkers and therapeutic targets in breast cancer:
Quo vadis? World J Clin Oncol 2014; 5: 71-81. http://dx.doi. org/10.5306/wjco.v5.i2.71

[87] ZHIKE C, YATE-CHING Y, YUANZHONG W, ZHENG L, HEI JC et al. Down-regulation of program cell death 4 (PDCD4) is associated with aromatase inhibitor resistance and a poor prognosis in estrogen receptor-positive breast cancer. Breast Cancer Res Treat 2015l; 152: 29-39. http:// dx.doi.org/10.1007/s10549-015-3446-8

[88] LI X, MERTENS-TALCOTT SU, ZHANG S, KIM K, BALL J et al. MicroRNA-27a Indirectly Regulates Estrogen Receptor \{alpha\} Expression and Hormone Responsiveness in MCF-7 Breast Cancer Cells. Endocrinology 2010; 151: 2462-2473. http://dx.doi.org/10.1210/en.2009-1150

[89] MERTENS-TALCOTT SU, CHINTHARLAPALLI S, LI X, SAFE S. The oncogenic microRNA-27a targets genes that regulate specificity protein transcription factors and the G2-M checkpoint in MDA-MB-231 breast cancer cells. Cancer Res 2007; 67: 11001-11011. http://dx.doi.org/10.1158/0008-5472. CAN-07-2416

[90] GE YF, SUN J, JIN CJ, CAO BQ, JIANG ZF et al. AntagomiR-27a targets FOXO3a in glioblastoma and suppresses U87 cell growth in vitro and in vivo. Asian Pac J Cancer Prev 2013; 14: 963-968. http://dx.doi.org/10.7314/ APJCP.2013.14.2.963

[91] YANG Z, ZHANG B, LIU B, XIE Y, CAO X. Combined Runx2 and Snail overexpression is associated with a poor prognosis in breast cancer. Tumour Biol 2015; 36: 4565-4573. http:// dx.doi.org/10.1007/s13277-015-3101-3

[92] JIANG Y, ZOU L, LU WQ, ZHANG Y, SHEN AG. Foxo3a expression is a prognostic marker in breast cancer. PLoS One 2013; 8: e70746. http://dx.doi.org/10.1371/journal. pone. 0070746 